\title{
Pathologic differential diagnosis of metastatic carcinoma in the liver
}

\author{
Jeong Hwan Park ${ }^{1,2}$ and Jung Ho Kim ${ }^{2,3}$ \\ 'Department of Pathology, Seoul Metropolitan Government-Seoul National Uiversity Boramae Medical Center, Seoul; ${ }^{2}$ Department of \\ Pathology, Seoul National University College of Medicine, Seoul; ${ }^{3}$ Department of Pathology, Seoul National University Hospital, Seoul, \\ Korea
}

The liver is one of the most common sites to which malignancies preferentially metastasize. Although a substantial number of liver malignancies are primary tumors, including hepatocellular carcinoma and intrahepatic cholangiocarcinoma, the metastasis of carcinomas to the liver is relatively common and frequently encountered in clinical settings. Representative carcinomas that frequently metastasize to the liver include colorectal carcinoma, breast carcinoma, neuroendocrine tumors, lung carcinoma, and gastric carcinoma. The diagnostic confirmation of suspected metastatic lesions in the liver is generally achieved through a histopathologic examination of biopsy tissues. Although morphology is the most important feature for a pathologic differential diagnosis of metastatic carcinomas, immunohistochemical studies facilitate the differentiation of metastatic carcinoma origins and subtypes. Useful immunohistochemical markers for the differential diagnosis of metastatic carcinomas in the liver include cytokeratins (CK7, CK19, and CK20), neuroendocrine markers (CD56, synaptophysin, and chromogranin A), and tissue-specific markers (CDX2, SATB2, TTF-1, GCDFP-15, mammaglobin, etc.). Here, we provide a brief review about the pathologic differential diagnosis of major metastatic carcinomas in the liver. (Clin Mol Hepatol 2019;25:12-20)

Keywords: Neoplasm metastasis; Liver neoplasms; Pathology; Immunohistochemistry

\section{INTRODUCTION}

Primary liver cancer is a malignant tumor that arises from hepatocytes and intrahepatic bile ducts, or more rarely, mesenchymal cells in the liver., ${ }^{1,2}$ Worldwide, 854 thousand new cases of liver cancer emerged and 810 thousand deaths occurred owing to liver cancer. This cancer is associated with the sixth-highest incidence and fourth-highest mortality among the different types of cancers. $^{3}$ In Korea, liver cancer is associated with the sixth-highest in- cidence and second-highest mortality among the different types of cancers, with 15,757 new cases and 11,311 deaths, respectively. ${ }^{4}$ Most primary liver cancers are hepatocellular carcinomas and intrahepatic cholangiocarcinomas. ${ }^{1,2}$ Hepatocellular carcinoma is defined as a malignant epithelial tumor that shows hepatocellular differentiation and is the most common histologic type of primary liver cancer. ${ }^{1}$ The incidence of hepatocellular carcinoma is highest in East Asia (including South Korea). Chronic viral infection (hepatitis B or C virus) and alcohol consumption are the leading causes

\section{Abbreviations:}

CD56, cluster of differentiation molecule 56; CDX2, caudal type homeobox 2; CK5/6, cytokeratin 5/6; CK7, cytokeratin 7; CK19, cytokeratin 19; CK20, cytokeratin 20; GCDFP-15, gross cystic disease fluid protein 15; MUC5AC, mucin 5AC; NST, no special type; SATB2, special AT-rich sequence-binding protein 2; TTF-1, thyroid transcription factor 1

\section{Corresponding author : Jung Ho Kim}

Department of Pathology, Seoul National University Hospital, 101 Daehak-ro, Jongno-gu, Seoul 03080, Korea

Tel: +82-2-2072-2828, Fax: +82-2-743-5530

E-mail: junghokim@snuh.org

https://orcid.org/0000-0002-6031-3629 
of hepatocellular carcinoma, and most hepatocellular carcinomas arise in cirrhotic tissue. Intrahepatic cholangiocarcinoma is defined as a malignant tumor with biliary epithelial differentiation. ${ }^{2}$ Along with hepatocellular carcinoma, intrahepatic cholangiocarcinoma is the second most common histologic type of primary liver cancer. The incidence of intrahepatic cholangiocarcinoma is highest in Asia, including South Korea, where Clonorchis sinensis is endemic. Most intrahepatic cholangiocarcinomas are histologically adenocarcinomas.

Secondary liver cancer is a malignant tumor that metastasizes to the liver from an extrahepatic origin. ${ }^{5}$ Secondary liver cancer is much more common in Europe and North America, whereas primary liver cancer is more common in south-east Asia, including South Korea. ${ }^{5-7}$ Secondary liver cancer usually develops in non-cirrhotic liver parenchyme. ${ }^{5}$ Because the liver receives a dual blood supply (systemic [arterial] and portal [venous]), the liver is one of the most common hematogenous metastatic sites. Secondary liver cancers are most commonly carcinomas, followed by melanoma, sarcoma, and lymphoma. Among carcinomas, adenocarcinoma comprises $70 \%$ of carcinomas, and squamous cell carcinoma follows. The major primary cancers that metastasize to the liver are colorectal carcinoma, breast carcinoma, neuroendocrine tumors, lung carcinoma, and gastric carcinoma. In general, immunohistochemical studies and histomorphologic examinations are very useful for the pathologic differential diagnosis of metastatic tumors.

In this review, we focus on the pathologic differential diagnosis of metastatic carcinomas in the liver. We summarize the pathologic features of major extrahepatic carcinomas that frequently metastasize to the liver, including colorectal carcinoma, breast carcinoma, neuroendocrine tumors, lung carcinoma, and gastric carcinoma, with emphasis on their immunohistochemical features.

\section{PATHOLOGIC FEATURES OF MAJOR META- STATIC CARCINOMAS IN THE LIVER}

\section{Metastatic colorectal carcinoma}

Adenocarcinoma accounts for more than $90 \%$ of colorectal carcinomas. ${ }^{8}$ Adenocarcinoma is a malignant epithelial tumor that shows gland formation, and based on the degree of gland formation, adenocarcinomas can be graded as one of the three differentiation types: well differentiated, moderately differentiated, and poorly differentiated. ${ }^{9}$ According to a study conducted in the
Netherlands, approximately $20 \%$ of patients with colorectal carcinoma present metastatic lesions at diagnosis, ${ }^{10}$ and a Swiss group revealed that the overall metastasis rate of colorectal carcinoma was approximately $30 \%$. $^{11}$ The liver is the most common metastatic site of colorectal carcinoma, and the main differential diagnosis of a liver metastatic lesion of colorectal carcinoma is primary intrahepatic cholangiocarcinoma, as colorectal carcinoma is mostly adenocarcinoma. Histologically, colorectal adenocarcinoma is composed of atypical epithelial cells with various degrees of glandular differentiation and invasion (Fig. 1A), ${ }^{8,9}$ Histologic variants of colorectal adenocarcinomas include mucinous, signet ring cell, medullary, micropapillary, serrated, and cribriform-comedo subtypes, according to the latest World Health Organization (WHO) classification of tumors of the digestive system. ${ }^{9}$ Desmoplastic stroma, a type of fibrous proliferation, can be seen around invasive carcinoma cells. Another frequent characteristic is "dirty necrosis," which is a form of necrotic debris, in glandular lumen. Immunohistochemically, cytokeratin 7 (CK7) negative, cytokeratin 20 (CK20) positive, and caudal-type homeobox 2 (CDX2) positive are the most common immunophenotypes of colorectal carcinoma (Fig. 2A, Table 1). ${ }^{8,9,12,13}$ CDX2 is a highly sensitive and specific marker for the detection of intestinal-origin or intestinal-type epithelial cells, and $>90 \%$ of adenocarcinomas of the colorectum show diffuse and strong nuclear expression. ${ }^{14-16}$ In addition to CDX2, Special AT-rich sequence-binding protein 2 (SATB2) is also a specific immunohistochemical marker for epithelial tumors of the small and large intestines and the appendix. ${ }^{17}$ Thus, the combination of CDX2 and SATB2 can be used as a specific marker panel for the diagnosis of metastatic colorectal carcinoma in the liver. ${ }^{17}$ A small subset of poorly differentiated carcinomas of the colorectum can show loss of CDX2 and/or CK20 expression. ${ }^{18}$ Therefore, it should be noted that CDX2/CK20-negative colorectal carcinoma can occasionally metastasize to the liver.

\section{Metastatic breast carcinoma}

Breast cancer is a malignant tumor that arises in the breast, and most breast cancers are invasive breast carcinomas. ${ }^{19}$ Among the histologic types of breast carcinoma, invasive carcinoma of no special type (NST) is the largest group and is commonly known as invasive ductal carcinoma. ${ }^{20}$ Metastasis of breast cancer occurs in about $20-30 \%$ of patients, ${ }^{21}$ and approximately $10-15 \%$ of patients develop distant metastasis within three years of primary cancer detection. ${ }^{22}$ The common metastatic sites are bone, lung, and liver. ${ }^{23}$ As $>90 \%$ of breast cancers are diagnosed as NST in- 
vasive carcinoma, which is characterized by frequent tubule formation that resembles adenocarcinoma, the main differential diagnosis of metastatic breast carcinoma in the liver is primary intrahepatic cholangiocarcinoma. Histologically, breast carcinoma is composed of atypical epithelial cells with uniform or highly pleomorphic nuclei, and tubular, glandular, cribriform, or solid structures can be observed (Fig. 1B). ${ }^{20}$ The tumor border shows infiltrative or pushing margins, and the stromal component shows extreme variability. Invasive lobular carcinoma is the second most common histologic type of breast carcinoma, following ductaltype (usually NST) invasive carcinoma. Invasive lobular carcinoma is morphologically characterized by single-cell or single-file type infiltration of poorly cohesive atypical epithelial cells, which show relatively monotonous nuclei. Immunohistochemically, CK7-positivity and CK20-negativity are the most common breast carcinoma immunophenotypes (Fig. 2B, Table 1). ${ }^{12,13}$ A comparison of estrogen receptor, progesterone receptor, and human epidermal growth factor receptor 2 immuno-profiles between primary breast carcinoma and metastatic carcinoma in the liver aids the differential diagnosis. In addition, immunohistochemical studies for tissue-specific markers, such as gross cystic disease fluid protein 15 (GCDFP-15) and mammaglobin, will be helpful. ${ }^{13,24-26}$ However, it should be noted that GCDFP-15 and mammaglobin are highly specific but less sensitive markers for breast-origin carcinomas. The loss of E-cadherin expression in tumor cells is a useful immunohistochemical feature for the confirmation of lobular carcinoma.

\section{Metastatic neuroendocrine tumor}

Neuroendocrine tumors are defined as neoplasms that are composed of atypical epithelial cells with neuroendocrine differentiation. ${ }^{27}$ Neuroendocrine tumors are usually found in the small intestine, appendix, rectum, pancreas, and lung. ${ }^{28,29}$ Neuroendocrine tumors have a site-specific staging system and can be graded as grade 1, 2, or 3 based on mitotic count or Ki-67 labelling index. ${ }^{27}$ Gastroenteropancreatic neuroendocrine tumors are divided into neuroendocrine tumor grades 1 or 2 and neuroendocrine carcinoma. Neuroendocrine tumors grades 1 and 2 show relatively welldifferentiated neoplasm and are composed of atypical epithelial cells that resemble normal endocrine cells (Fig. 1C). Neuroendocrine carcinomas are poorly differentiated malignant neoplasms that are composed of small or large cells with high mitotic activity and marked nuclear atypia. Neuroendocrine tumor grade 1, formerly called carcinoid tumor, can also metastasize. ${ }^{30}$ The metastases of neuroendocrine tumors have been observed in about 20$25 \%$ of patients, and the liver is the most common metastatic
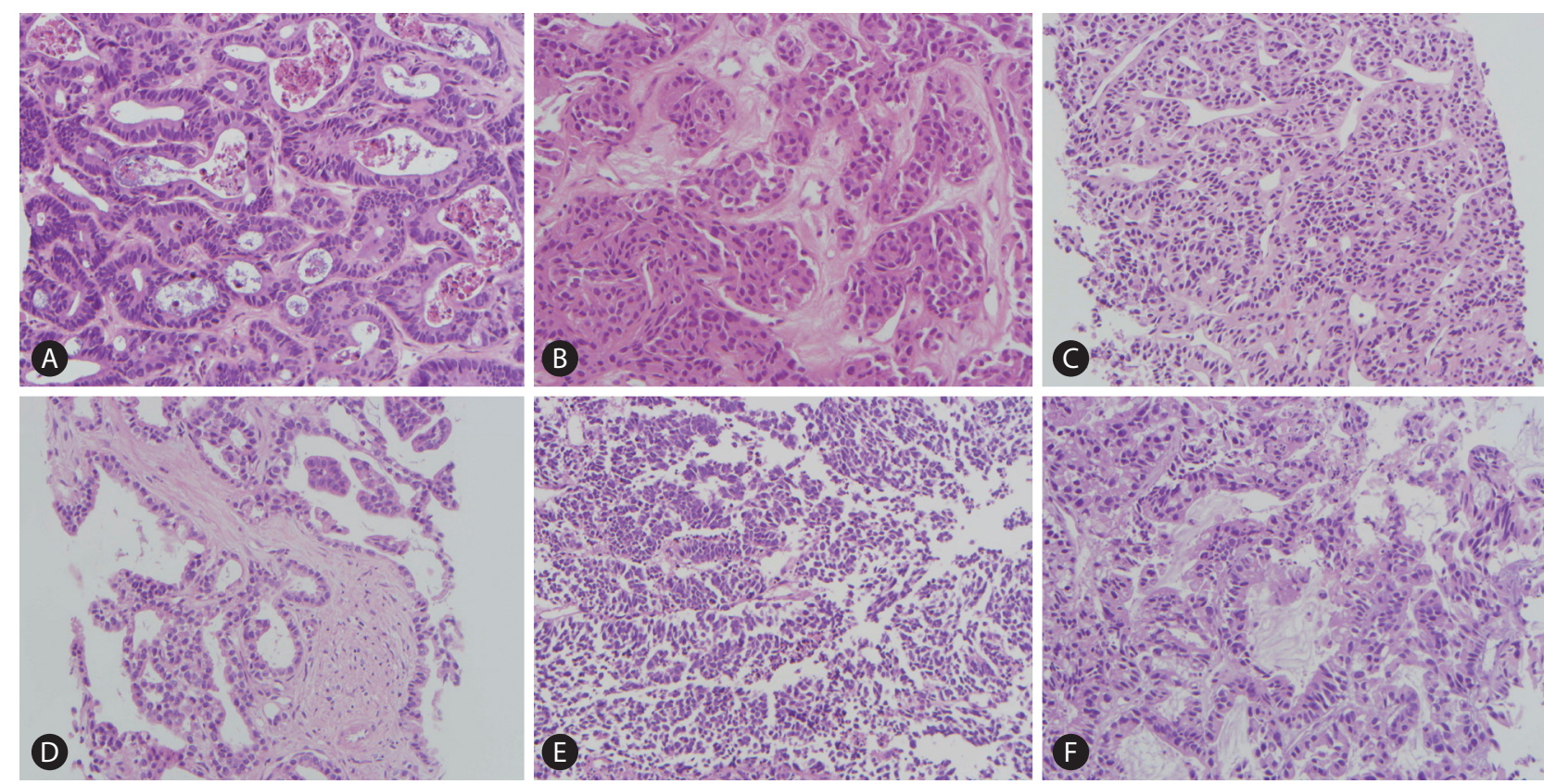

Figure 1. Histopathologic features of metastatic carcinomas in the liver (Hematoxylin and Eosin stain, original magnification ×200). (A) Metastatic colorectal carcinoma (adenocarcinoma). (B) Metastatic breast carcinoma (invasive carcinoma of no special type). (C) A metastatic neuroendocrine tumor. (D) Metastatic non-small cell lung carcinoma (adenocarcinoma). (E) Metastatic small cell lung carcinoma. (F) Metastatic gastric carcinoma (adenocarcinoma). 
site. $^{29}$ Small intestinal neuroendocrine tumors encompass more than half of the liver metastases of all neuroendocrine tumors. Histologically, neuroendocrine tumors are composed of uniform cells with light eosinophilic cytoplasm, and the tumor cells are arranged in trabeculae and/or pseudorosette patterns. ${ }^{31}$ Both hepatocellular carcinoma and intrahepatic cholangiocarcinoma are considered in the differential diagnoses of metastatic neuroendocrine tumors in the liver. Immunohistochemically, neuroendocrine tumors show variable CK7 and CK20 positivity, based on anatomical site (Table 1). 12,13,32 Characteristically, neuroendocrine tumors show immunoreactivity for neuroendocrine markers, including chromogranin A, synaptophysin, and cluster of differentiation molecule 56 (CD56) (Fig. 2C). Tissue specific markers, such as HepPar1 and Arginase-1 for hepatocellular carcinoma, along with CK7 and CK20 immunophenotypes facilitate the differentiation of metastatic neuroendocrine tumors from hepatocellular carcinoma and intrahepatic cholangiocarcinoma. ${ }^{13}$ Primary hepatic neuroendocrine tumors and hepatocellular carcinomas with neuroendocrine differentiation have been reported; however, both cases are extremely rare. $^{33,34}$

\section{Metastatic lung carcinoma}

Lung carcinoma is a malignant epithelial tumor that originates in the lungs. Lung carcinomas are largely classified into two main categories: non-small cell lung carcinoma and small cell lung carcinoma. ${ }^{35}$ Non-small cell lung carcinomas are further classified into adenocarcinoma, squamous cell carcinoma, and large cell carcinoma based on histologic features. Metastases of small cell lung carcinomas can occur in about $60 \%$ of patients, and the liver is the most common metastatic site, after pleural and/or pericardial fluids. ${ }^{36}$ In patients with non-small cell lung carcinoma, metastases occur in approximately $40-50 \%$ of cases, and liver metastases account for $10-14 \%$ of the total metastases. ${ }^{37,38}$ Adenocarcinoma and squamous cell carcinoma account for most non-small cell lung carcinomas. ${ }^{35}$ Adenocarcinoma shows acinar, papillary, micropapillary, lepidic, or solid growth patterns. Intrahepatic cholangiocarcinoma is the main differential diagnosis of metastatic pulmonary adenocarcinoma of the liver (Fig. 1D). Squamous cell carcinoma shows keratinization and/or intercellular bridges, and hepatocellular carcinoma can be included as a differential diagnosis of metastatic squamous cell carcinoma in the liver. Small cell lung carcinoma is composed of atypical, small, and round
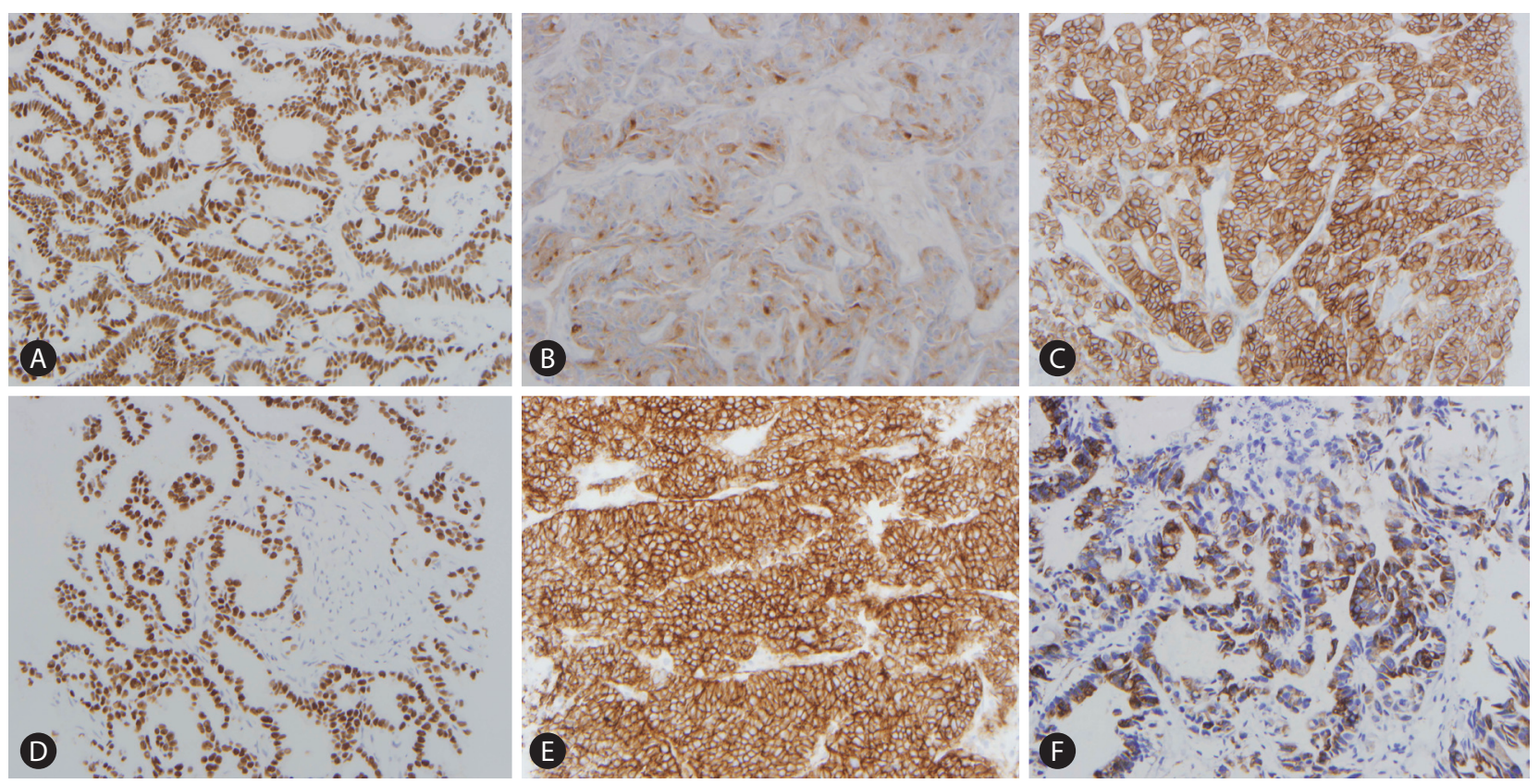

Figure 2. Immunohistochemical features of metastatic carcinomas in the liver (original magnification X200). (A) CDX2 positivity in metastatic colorectal carcinoma. (B) GCDFP-15 positivity in metastatic breast carcinoma. (C) CD56 positivity in a metastatic neuroendocrine tumor. (D) TTF-1 positivity in metastatic pulmonary adenocarcinoma. (E) CD56 positivity in metastatic small cell lung carcinoma. (F) MUC5AC positivity in metastatic gastric carcinoma. CDX2, caudal type homeobox 2; GCDFP-15, gross cystic disease fluid protein 15; CD56, cluster of differentiation molecule 56; TTF-1, thyroid transcription factor 1; MUC5AC, mucin 5AC. 


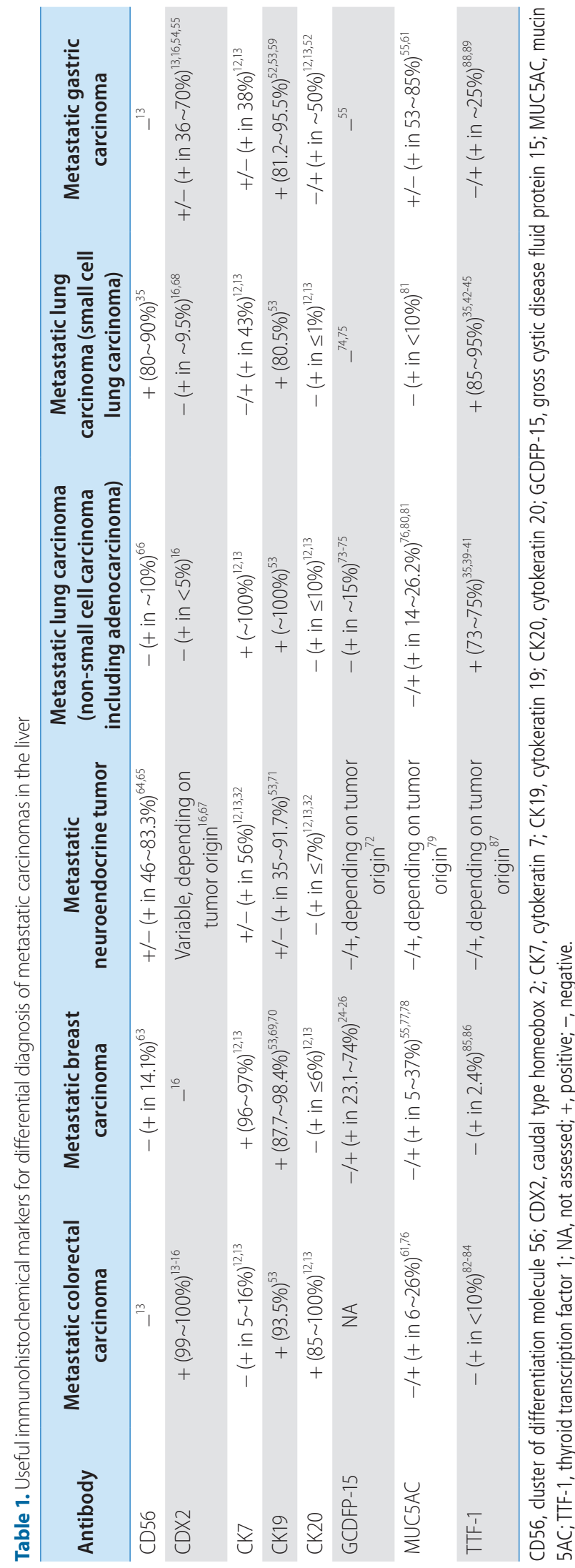

epithelial cells with scant cytoplasm and finely-dispersed and granular nuclear chromatin (Fig. 1E). Combined hepatocellular-cholangiocarcinoma with stem cell features as well as poorly-differentiated hepatocellular carcinoma or intrahepatic cholangiocarcinoma can be considered as differential diagnoses. Immunohistochemically, lung adenocarcinoma usually shows immunoreactivity for CK7, thyroid transcription factor 1 (TTF-1), and napsin A, whereas lung squamous cell carcinoma shows immunoreactivity for cytokeratin 5/6 (CK5/6), p63, and p40 (Fig. 2D, Table 1)..$^{12,13,35,39-41}$ Small cell lung carcinoma shows positivity for at least one neuroendocrine marker, including CD56, synaptophysin, and chromogranin A (Fig. 2E, Table 1). TTF-1 positivity has also been reported in $85-95 \%$ of small cell lung carcinomas. ${ }^{35,42-45}$

\section{Metastatic gastric carcinoma}

Gastric carcinoma is defined as a malignant epithelial neoplasm that arises in the stomach. ${ }^{46}$ According to a study of Swedish patients, 26\% of gastric carcinomas develop distant metastases, and the liver (48\% of all metastases) is the most common metastatic site. ${ }^{47}$ Histologically, tubular adenocarcinoma is the most common histological subtype of gastric carcinoma (Fig. 1F). Other histological gastric carcinoma variants include poorly cohesive carcinoma (including signet ring cell carcinoma), papillary adenocarcinoma, and mucinous adenocarcinoma. ${ }^{48}$ As adenocarcinoma is the most common histologic subtype of gastric carcinoma, the main differential diagnosis of metastatic gastric carcinoma in the liver is intrahepatic cholangiocarcinoma. Immunohistochemically, CK7-positivity and CK20-negativity are the most common immunophenotype of gastric carcinoma. However, a substantial number of patients with gastric carcinoma can show CK7-positive and CK20-positive immunophenotypes (Table 1). 12,13,49-52 Both gastric carcinoma and intrahepatic cholangiocarcinoma show similar cytokeratin 19 (CK19) positivity. ${ }^{50,52,53}$ CDX2 might facilitate the differentiation of metastatic gastric carcinoma in the liver from intrahepatic cholangiocarcinoma because $60.9 \%$ of patients with gastric carcinoma have shown immunoreactivity, compared to $13 \%$ of those with biliary cancers. ${ }^{13,16,54,55}$ Rarely, hepatoid adenocarcinoma can occur in less than $5 \%$ of patients with gastric carcinoma. ${ }^{56-58}$ The metastasis of hepatoid adenocarcinoma to the liver needs to be differentially diagnosed from hepatocellular carcinoma. Both carcinomas are AFP-positive, but CK19 positivity is more frequent in metastatic hepatoid adenocarcinoma than in primary hepatocellular carcinoma. ${ }^{59}$ Mucin 5 AC (MUC5AC), a gastric-type mucin, is detected in $38-85 \%$ of gastric cancers (GCs) 
(Fig. 2F). ${ }^{55,60,61}$ However, MUC5AC should be used with caution for the differential diagnosis of metastatic $\mathrm{GC}$ in the liver because MUC5AC positivity can be observed in $42-61.1 \%$ of intrahepatic cholangiocarcinomas and is rarely observed in adenocarcinomas from other sites (Table 1). ${ }^{61-89}$

\section{CONCLUSION}

Metastatic carcinoma in the liver can be observed in various patients with cancer. It is important to correctly diagnose the histologic type and the primary site of the metastatic lesions to establish the optimal treatment strategy. A constellation of clinical information that includes radiologic findings and laboratory results is also important for the correct pathologic diagnosis of metastatic tumors in the liver. In a pathologic aspect, background liver pathology is helpful for the differential diagnosis between primary and secondary liver cancers. If secondary liver cancer is suspected, a pathologic review of the potential primary cancer is helpful. Immunohistochemical studies with cytokeratins, neuroendocrine markers, and tissue-specific markers are sometimes essential for the differential diagnosis of metastatic carcinomas in the liver.

\section{Authors' contribution}

JHP performed a literature review and drafted the manuscript. JHK conceived the study and revised the manuscript.

\section{Acknowledgements}

This study was supported by the National Research Foundation of Korea grant funded by the Korea government (Ministry of Science and ICT) (2016R1C1B2010627).

\section{Conflicts of Interest}

The authors have no conflicts to disclose.

\section{REFERENCES}

1. Theise ND, Curado MP, Franceschi S, Hytiroglou P, Kudo M, Park YN, et al. Hepatocellular carcinoma. In: Bosman FT, Carneiro F, Hruban $\mathrm{RH}$, Theise ND, eds. WHO classification of tumours of the digestive system. 4th ed. Lyon: World Health Organization, 2010:205-216.

2. Nakanuma Y, Curado MP, Franceschi S, Gores G, Paradis V, Sripa B, et al. Intrahepatic cholangiocarcinoma. In: Bosman FT, Carneiro F, Hruban RH, Theise ND, eds. WHO classification of tumours of the digestive system. 4th ed. Lyon: World Health Organization, 2010:217224.

3. Global Burden of Disease Cancer Collaboration, Fitzmaurice C, Allen C, Barber RM, Barregard L, Bhutta ZA, et al. Global, regional, and national cancer incidence, mortality, years of life lost, years lived with disability, and disability-adjusted life-years for 32 cancer groups, 1990 to 2015: a systematic analysis for the global burden of disease study. JAMA Oncol 2017;3:524-548.

4. Jung KW, Won YJ, Kong HJ, Lee ES; Community of PopulationBased Regional Cancer Registries. Cancer statistics in Korea: incidence, mortality, survival, and prevalence in 2015. Cancer Res Treat 2018:50:303-316.

5. lacobuzio-Donahue C, Ferrell L. Secondary tumours of the liver. In: Bosman FT, Carneiro F, Hruban RH, Theise ND, eds. WHO classification of tumours of the digestive system. 4th ed. Lyon: World Health Organization, 2010:251-253.

6. Motola-Kuba D, Zamora-Valdés $D$, Uribe $M$, Méndez-Sánchez $N$. Hepatocellular carcinoma. An overview. Ann Hepatol 2006;5:16-24.

7. Bosch FX, Ribes J, Díaz M, Cléries R. Primary liver cancer: worldwide incidence and trends. Gastroenterology 2004;127(5 Suppl 1):S5-S16.

8. Hamilton SR, Bosman FT, Boffetta P, Ilyas M, Morreau H, Nakamura $\mathrm{SI}$, et al. Carcinoma of the colon and rectum. In: Bosman FT, Carneiro $F$, Hruban RH, Theise ND, eds. WHO classification of tumours of the digestive system. 4th ed. Lyon: World Health Organization, 2010:134-146.

9. Fleming M, Ravula S, Tatishchev SF, Wang HL. Colorectal carcinoma: pathologic aspects. J Gastrointest Oncol 2012;3:153-173.

10. van der Geest LG, Lam-Boer J, Koopman M, Verhoef C, Elferink MA, de Wilt JH. Nationwide trends in incidence, treatment and survival of colorectal cancer patients with synchronous metastases. Clin Exp Metastasis 2015:32:457-465.

11. Riihimäki $M$, Hemminki $A$, Sundquist J, Hemminki K. Patterns of metastasis in colon and rectal cancer. Sci Rep 2016;6:29765.

12. Chu P, Wu E, Weiss LM. Cytokeratin 7 and cytokeratin 20 expression in epithelial neoplasms: a survey of 435 cases. Mod Pathol 2000;13:962-972.

13. Bhargava R, Dabbs DJ. Immunohistology of metastatic carcinoma of unknown primary site. In: Dabbs DJ, ed. Diagnostic immunohistochemistry. 4th ed. Philadelphia: Elsevier Saunders, 2014:204-244.

14. Werling RW, Yaziji H, Bacchi CE, Gown AM. CDX2, a highly sensitive and specific marker of adenocarcinomas of intestinal origin: an immunohistochemical survey of 476 primary and metastatic carcinomas. Am J Surg Pathol 2003;27:303-310.

15. Kaimaktchiev V, Terracciano L, Tornillo L, Spichtin H, Stoios D, Bundi $M$, et al. The homeobox intestinal differentiation factor CDX2 is selectively expressed in gastrointestinal adenocarcinomas. Mod Pathol 
2004;17:1392-1399.

16. Moskaluk CA, Zhang H, Powell SM, Cerilli LA, Hampton GM, Frierson $\mathrm{HF}$ Jr. Cdx2 protein expression in normal and malignant human tissues: an immunohistochemical survey using tissue microarrays. Mod Pathol 2003;16:913-919.

17. Dabir PD, Svanholm H, Christiansen JJ. SATB2 is a supplementary immunohistochemical marker to CDX2 in the diagnosis of colorectal carcinoma metastasis in an unknown primary. APMIS 2018;126:494-500.

18. Kim JH, Rhee YY, Bae JM, Cho NY, Kang GH. Loss of CDX2/CK20 expression is associated with poorly differentiated carcinoma, the $\mathrm{CpG}$ island methylator phenotype, and adverse prognosis in microsatelliteunstable colorectal cancer. Am J Surg Pathol 2013;37:1532-1541.

19. Colditz G, Chia KS. Invasive breast carcinoma: introduction and general features. In: Lakhani SR, Ellis IO, Schnitt SJ, Tan PH, van de Vijver MJ, eds. WHO classification of tumours of the breast. 4th ed. Lyon: World Health Organization, 2012:14-31.

20. Ellis IO, Collins L, Ichihara S, MacGrogan G. Invasive carcinoma of no special type. In: Lakhani SR, Ellis IO, Schnitt SJ, Tan PH, van de Vijver MJ, eds. WHO classification of tumours of the breast. 4th ed. Lyon: World Health Organization, 2012:34-38.

21. DeVita VT Jr, Hellman S, Rosenberg SA. Cancer: principles and practice of oncology. 4th ed. Philadelphia: Lippincott Williams and Wilkins, 1993:1264-1332.

22. Weigelt B, Peterse JL, van't Veer LJ. Breast cancer metastasis: markers and models. Nat Rev Cancer 2005;5:591-602.

23. Lee YT. Breast carcinoma: pattern of metastasis at autopsy. I Surg Oncol 1983;23:175-180.

24. Bhargava R, Beriwal S, Dabbs DJ. Mammaglobin vs GCDFP-15: an immunohistologic validation survey for sensitivity and specificity. Am J Clin Pathol 2007;127:103-113.

25. Wick MR, Lillemoe TJ, Copland GT, Swanson PE, Manivel JC, Kiang DT. Gross cystic disease fluid protein-15 as a marker for breast cancer: immunohistochemical analysis of 690 human neoplasms and comparison with alpha-lactalbumin. Hum Pathol 1989;20:281-287.

26. Darb-Esfahani S, von Minckwitz G, Denkert C, Ataseven B, Högel B, Mehta K, et al. Gross cystic disease fluid protein 15 (GCDFP-15) expression in breast cancer subtypes. BMC Cancer 2014;14:546.

27. Rindi G, Arnold R, Bosman FT, Capella C, Klimstra DS, Klöppel G, et al. Nomenclature and classification of neuroendocrine neoplasms of the digestive system. In: Bosman FT, Carneiro F, Hruban RH, Theise ND, eds. WHO classification of tumours of the digestive system. 4th ed. Lyon: World Health Organization, 2010:13-14.

28. Dasari A, Shen C, Halperin D, Zhao B, Zhou S, Xu Y, et al. Trends in the incidence, prevalence, and survival outcomes in patients with neuroendocrine tumors in the United States. JAMA Oncol 2017;3:1335-1342.

29. Riihimäki M, Hemminki A, Sundquist $K$, Sundquist J, Hemminki K. The epidemiology of metastases in neuroendocrine tumors. Int J
Cancer 2016;139:2679-2686.

30. Zuetenhorst JM, Taal BG. Metastatic carcinoid tumors: a clinical review. Oncologist 2005;10:123-131.

31. Capella C, Arnold R, Klimstra DS, Klöppel G, Komminoth P, Solcia E, et al. Neuroendocrine neoplasms of the small intestine. In: Bosman FT, Carneiro F, Hruban RH, Theise ND, eds. WHO classification of tumours of the digestive system. 4th ed. Lyon: World Health Organization, 2010:102-107.

32. Cai YC, Banner B, Glickman J, Odze RD. Cytokeratin 7 and 20 and thyroid transcription factor 1 can help distinguish pulmonary from gastrointestinal carcinoid and pancreatic endocrine tumors. Hum Pathol 2001;32:1087-1093.

33. Song JE, Kim BS, Lee CH. Primary hepatic neuroendocrine tumor: a case report and literature review. World I Clin Cases 2016;4:243-247.

34. Yamaguchi R, Nakashima O, Ogata T, Hanada K, Kumabe T, Kojiro M. Hepatocellular carcinoma with an unusual neuroendocrine component. Pathol Int 2004;54:861-865.

35. Geisinger K, Moreira AL, Nicholson AG, Rami-Porta R, Travis WD, Yatabe $Y$, et al. Tumours of the lung. In: Travis WD, Brambilla $E$, Burke AP, Marx A, Nicholson AG, eds. WHO classification of tumours of the lung, pleura, thymus and heart. 4th ed. Lyon: World Health Organization, 2015:9-151.

36. Nakazawa K, Kurishima K, Tamura T, Kagohashi K, Ishikawa H, Satoh $\mathrm{H}$, et al. Specific organ metastases and survival in small cell lung cancer. Oncol Lett 2012;4:617-620.

37. Tamura T, Kurishima K, Nakazawa K, Kagohashi K, Ishikawa H, Satoh $\mathrm{H}$, et al. Specific organ metastases and survival in metastatic non-small-cell lung cancer. Mol Clin Oncol 2015;3:217-221.

38. Bauml J, Mick R, Zhang Y, Watt CD, Vachani A, Aggarwal C, et al. Determinants of survival in advanced non--small-cell lung cancer in the era of targeted therapies. Clin Lung Cancer 2013;14:581-591.

39. Rekhtman N, Ang DC, Sima CS, Travis WD, Moreira AL. Immunohistochemical algorithm for differentiation of lung adenocarcinoma and squamous cell carcinoma based on large series of whole-tissue sections with validation in small specimens. Mod Pathol 2011;24:1348-1359.

40. Stenhouse G, Fyfe N, King G, Chapman A, Kerr KM. Thyroid transcription factor 1 in pulmonary adenocarcinoma. J Clin Pathol 2004; 57:383-387.

41. Bishop JA, Sharma R, Illei PB. Napsin A and thyroid transcription factor-1 expression in carcinomas of the lung, breast, pancreas, colon, kidney, thyroid, and malignant mesothelioma. Hum Pathol 2010;41:20-25.

42. Johansson L. Histopathologic classification of lung cancer: relevance of cytokeratin and TTF-1 immunophenotyping. Ann Diagn Pathol 2004;8:259-267.

43. Ordóñez NG. Value of thyroid transcription factor-1 immunostaining in distinguishing small cell lung carcinomas from other small cell carcinomas. Am J Surg Pathol 2000;24:1217-1223. 
44. Kaufmann 0, Dietel M. Expression of thyroid transcription factor-1 in pulmonary and extrapulmonary small cell carcinomas and other neuroendocrine carcinomas of various primary sites. Histopathology 2000;36:415-420.

45. Sturm N, Rossi G, Lantuejoul S, Papotti M, Frachon S, Claraz C, et al. Expression of thyroid transcription factor-1 in the spectrum of neuroendocrine cell lung proliferations with special interest in carcinoids. Hum Pathol 2002;33:175-182.

46. Lauwers GY, Carneiro F, Graham DY, Curado MP, Franceschi S, Montgomery E, et al. Gastric carcinoma. In: Bosman FT, Carneiro F, Hruban RH, Theise ND, eds. WHO classification of tumours of the digestive system. 4th ed. Lyon: World Health Organization, 2010:4858.

47. Riihimäki M, Hemminki A, Sundquist $K$, Sundquist J, Hemminki K. Metastatic spread in patients with gastric cancer. Oncotarget 2016;7:52307-52316.

48. Hu B, El Hajj N, Sittler S, Lammert N, Barnes R, Meloni-Ehrig A. Gastric cancer: classification, histology and application of molecular pathology. J Gastrointest Oncol 2012;3:251-261.

49. Park SY, Kim HS, Hong EK, Kim WH. Expression of cytokeratins 7 and 20 in primary carcinomas of the stomach and colorectum and their value in the differential diagnosis of metastatic carcinomas to the ovary. Hum Pathol 2002;33:1078-1085.

50. Kim MA, Lee HS, Yang HK, Kim WH. Cytokeratin expression profile in gastric carcinomas. Hum Pathol 2004;35:576-581.

51. Takami H, Sentani K, Matsuda M, Oue N, Sakamoto N, Yasui W. Cytokeratin expression profiling in gastric carcinoma: clinicopathologic significance and comparison with tumor-associated molecules. Pathobiology 2012;79:154-161.

52. Gurbuz Y, Köse N. Cytokeratin expression patterns of gastric carcinomas according to Lauren and Goseki classification. Appl Immunohistochem Mol Morphol 2006;14:303-308.

53. Chu PG, Weiss LM. Keratin expression in human tissues and neoplasms. Histopathology 2002;40:403-439.

54. Park SY, Kim BH, Kim JH, Lee S, Kang GH. Panels of immunohistochemical markers help determine primary sites of metastatic adenocarcinoma. Arch Pathol Lab Med 2007;131:1561-1567.

55. Koyama T, Sekine S, Taniguchi H, Tsuda H, Ikegami M, Hano H, et al. Hepatocyte nuclear factor $4 \mathrm{~A}$ expression discriminates gastric involvement by metastatic breast carcinomas from primary gastric adenocarcinomas. Hum Pathol 2011;42:1777-1784.

56. Chang YC, Nagasue N, Abe S, Taniura H, Kumar DD, Nakamura T. Comparison between the clinicopathologic features of AFP-positive and AFP-negative gastric cancers. Am J Gastroenterol 1992;87:321-325.

57. Kato T, Takahashi H, Ida Y, Watanabe Y, Sato Y, Takeda B. Immunocytohistochemical studies of AFP producing gastric cancer-cytomorphology and characteristics of AFP positive cells. Rinsho Byori 1993;41:1024-1030.
58. Motoyama T, Aizawa K, Watanabe H, Fukase M, Saito K. alphaFetoprotein producing gastric carcinomas: a comparative study of three different subtypes. Acta Pathol Jpn 1993;43:654-661.

59. Terracciano LM, Glatz K, Mhawech P, Vasei M, Lehmann FS, Vecchione $R$, et al. Hepatoid adenocarcinoma with liver metastasis mimicking hepatocellular carcinoma: an immunohistochemical and molecular study of eight cases. Am J Surg Pathol 2003;27:1302-1312.

60. Krasinskas AM, Goldsmith JD. Immunohistology of the gastrointestinal tract. In: Dabbs DJ, ed. Diagnostic immunohistochemistry. 4th ed. Philadelphia: Elsevier Saunders, 2014:508-539.

61. Wong HH, Chu P. Immunohistochemical features of the gastrointestinal tract tumors. J Gastrointest Oncol 2012;3:262-284.

62. Park SY, Roh SJ, Kim YN, Kim SZ, Park HS, Jang KY, et al. Expression of MUC1, MUC2, MUC5AC and MUC6 in cholangiocarcinoma: prognostic impact. Oncol Rep 2009;22:649-657.

63. Wachter DL, Hartmann A, Beckmann MW, Fasching PA, Hein A, Bayer $C M$, et al. Expression of neuroendocrine markers in different molecular subtypes of breast carcinoma. Biomed Res Int 2014;2014:408459.

64. Terada T. Carcinoid tumors of digestive organs: a clinicopathologic study of 13 cases. Gastroenterology Res 2009;2:35-37.

65. Egashira A, Morita M, Kumagai R, Taguchi KI, Ueda M, Yamaguchi $S$, et al. Neuroendocrine carcinoma of the esophagus: clinicopathological and immunohistochemical features of 14 cases. PLoS One 2017; 12:e0173501.

66. Hammar SP, Dacic S. Immunohistology of lung and pleural neoplasms. In: Dabbs DJ, ed. Diagnostic immunohistochemistry. 4th ed. Philadelphia: Elsevier Saunders, 2014:386-478.

67. Saqi A, Alexis D, Remotti F, Bhagat G. Usefulness of CDX2 and TTF1 in differentiating gastrointestinal from pulmonary carcinoids. Am J Clin Pathol 2005;123:394-404.

68. Bari MF, Brown H, Nicholson AG, Kerr KM, Gosney JR, Wallace WA, et al. BAI3, CDX2 and VIL1: a panel of three antibodies to distinguish small cell from large cell neuroendocrine lung carcinomas. Histopathology 2014;64:547-556.

69. Alvarenga CA, Paravidino PI, Alvarenga M, Dufloth R, Gomes M, Zeferino LC, et al. Expression of CK19 in invasive breast carcinomas of special histological types: implications for the use of one-step nucleic acid amplification. J Clin Pathol 2011;64:493-497.

70. Fujisue M, Nishimura R, Okumura Y, Tashima R, Nishiyama Y, Osako $T$, et al. Clinical significance of CK19 negative breast cancer. Cancers (Basel) 2012:5:1-11.

71. Jain R, Fischer S, Serra S, Chetty R. The use of Cytokeratin 19 (CK19) immunohistochemistry in lesions of the pancreas, gastrointestinal tract, and liver. Appl Immunohistochem Mol Morphol 2010;18:9-15.

72. Richter-Ehrenstein C, Arndt J, Buckendahl AC, Eucker J, Weichert W, Kasajima $A$, et al. Solid neuroendocrine carcinomas of the breast: metastases or primary tumors? Breast Cancer Res Treat 
2010;124:413-417.

73. Striebel JM, Dacic S, Yousem SA. Gross cystic disease fluid protein(GCDFP-15): expression in primary lung adenocarcinoma. Am J Surg Pathol 2008;32:426-432.

74. Wang LJ, Greaves WO, Sabo E, Noble L, Tavares R, Ng T, et al. GCDFP-15 positive and TTF-1 negative primary lung neoplasms: a tissue microarray study of 381 primary lung tumors. Appl Immunohistochem Mol Morphol 2009;17:505-511.

75. Takeda Y, Tsuta K, Shibuki Y, Hoshino T, Tochigi N, Maeshima AM, et al. Analysis of expression patterns of breast cancer-specific markers (mammaglobin and gross cystic disease fluid protein 15) in lung and pleural tumors. Arch Pathol Lab Med 2008;132:239-243.

76. Lau SK, Weiss LM, Chu PG. Differential expression of MUC1, MUC2, and MUC5AC in carcinomas of various sites: an immunohistochemical study. Am J Clin Pathol 2004;122:61-69.

77. Pereira MB, Dias AJ, Reis CA, Schmitt FC. Immunohistochemical study of the expression of MUC5AC and MUC6 in breast carcinomas and adjacent breast tissues. J Clin Pathol 2001;54:210-213.

78. Rakha EA, Boyce RW, Abd El-Rehim D, Kurien T, Green AR, Paish EC, et al. Expression of mucins (MUC1, MUC2, MUC3, MUC4, MUC5AC and MUC6) and their prognostic significance in human breast cancer. Mod Pathol 2005;18:1295-1304.

79. Domori K, Nishikura K, Ajioka Y, Aoyagi Y. Mucin phenotype expression of gastric neuroendocrine neoplasms: analysis of histopathology and carcinogenesis. Gastric Cancer 2014;17:263-272.

80. Yu CJ, Shih JY, Lee YC, Shun CT, Yuan A, Yang PC. Sialyl Lewis antigens: association with MUC5AC protein and correlation with postoperative recurrence of non-small cell lung cancer. Lung Cancer 2005;47:59-67.

81. Lopez-Ferrer A, Curull V, Barranco C, Garrido M, Lloreta J, Real FX, et al. Mucins as differentiation markers in bronchial epithelium.
Squamous cell carcinoma and adenocarcinoma display similar expression patterns. Am J Respir Cell Mol Biol 2001;24:22-29.

82. Compérat $E$, Zhang F, Perrotin C, Molina T, Magdeleinat P, Marmey $B$, et al. Variable sensitivity and specificity of TTF-1 antibodies in lung metastatic adenocarcinoma of colorectal origin. Mod Pathol 2005;18:1371-1376.

83. Xu B, Thong N, Tan D, Khoury T. Expression of thyroid transcription factor-1 in colorectal carcinoma. Appl Immunohistochem Mol Morphol 2010;18:244-249.

84. Bae JM, Kim JH, Park JH, Park HE, Cho NY, Kang GH. Clinicopathological and molecular implications of aberrant thyroid transcription factor-1 expression in colorectal carcinomas: an immunohistochemical analysis of 1319 cases using three different antibody clones. Histopathology 2018;72:423-432.

85. Robens J, Goldstein L, Gown AM, Schnitt SJ. Thyroid transcription factor-1 expression in breast carcinomas. Am J Surg Pathol 2010;34:1881-1885.

86. Ni YB, Tsang JY, Shao MM, Chan SK, Tong J, To KF, et al. TTF-1 expression in breast carcinoma: an unusual but real phenomenon. Histopathology 2014;64:504-511.

87. Du EZ, Goldstraw P, Zacharias J, Tiffet O, Craig PJ, Nicholson AG, et al. TTF-1 expression is specific for lung primary in typical and atypical carcinoids: TTF-1-positive carcinoids are predominantly in peripheral location. Hum Pathol 2004;35:825-831.

88. Choi SM, Furth EE, Zhang PJ. Unexpected TTF-1 positivity in a subset of gastric adenocarcinomas. Appl Immunohistochem Mol Morphol 2016;24:603-607.

89. Pegolo E, Machin P, Damante G, Di Loreto C. TTF-1 positivity in 2 cases of adenocarcinoma of the gastrointestinal tract. Appl Immunohistochem Mol Morphol 2014;22:e27-e31. 